\title{
HUBUNGAN PENGETAHUAN, SIKAP, DUKUNGAN SUAMI, KONTROL PERILAKU, DAN NIAT IBU DENGAN PERILAKU KADARZI IBU BALITA GIZI KURANG
}

\author{
Aulidina Dwi Mustafyani, Trias Mahmudiono \\ Departemen Gizi Kesehatan, Fakultas Kesehatan Masyarakat \\ Universitas Airlangga, \\ Nama Penulis Utama: \\ Aulidina Dwi Mustafyani \\ Email: dina.auli@yahoo.co.id
}

\begin{abstract}
Lack of knowledge and attitude might lead to a state of poor behavior in society. Results of nutritional awareness family (KADARZI) survey in 2015 showed 24.09\% families and increased to $24.15 \%$ in 2016 of families who not aware of nutrition. The aim of the study was to analyze the relationship between knowledge and intention with mother of children under five malnutrition. This was a cross sectional study with 58 samples selected by simple random sampling. Subject in this study was the mother of malnourished children under five. The data were collected through interview using questionnaires, and analyzed using pearson correlation. Of the five indicators, families who weighing weight every months $(74.14 \%)$, consume a variety of foods (55.1\%), iodized salt (100.0\%), exclusive breastfeeding (51.72\%), and nutritional supplements (100.0\%). Most families were having medium level knowledge (53.4\%) and poor knowledge (46.6\%). There were association between family income $(p=0.040)$, knowledge $(p=0.033)$ and intention $(p=0.048)$ to the behavior of mother towards KADARZI. While attitude, subjective norm, and perceived behavioral control did not have relationship to the behavior of mother toward KADARZI. Knowledge and intention was related to enactment of KADARZI.
\end{abstract}

Keywords: nutritional awareness family, nutritional awareness family behavior, children under five malnutrition, knowledge, intention.

\begin{abstract}
ABSTRAK
Salah satu faktor rendahnya perilaku kesehatan di masyarakat karena pengetahuan dan sikapnya yang kurang. Hasil data survei KADARZI pada tahun 2015 keluarga yang belum KADARZI sebesar $24,09 \%$ dan meningkat pada tahun 2016 sebesar 24,15\%. Untuk menganalisis hubungan antara pengetahuan dan niat ibu dengan perilaku KADARZI ibu balita gizi kurang. Penelitian ini menggunakan desain cross sectional dengan besar sampel 58 responden yang dipilih menggunakan simple random sampling. Subjek dalam penelitian ini adalah ibu yang memiliki balita gizi kurang. Pengumpulan data dilakukan dengan wawancara menggunakan kuesioner. Uji statistika yang digunakan adalah uji pearson correlation. Dari lima indikator KADARZI, keluarga yang menimbang berat badan setiap bulan (74,14\%), konsumsi aneka ragam makanan (55,17\%), garam beryodium (100,0\%), ASI eksklusif (51,72\%), dan suplemen gizi $(100,0 \%)$. Pengetahuan sedang $(53,4 \%)$ dan kurang $(46,6 \%)$. Pendapatan keluarga $(\mathrm{p}=0,040)$, pengetahuan ibu mengenai KADARZI $(\mathrm{p}=0,033)$ dan niat ibu melakukan KADARZI $(\mathrm{p}=0,048)$ mempunyai hubungan yang signifikan dengan perilaku KADARZI. Sedangkan sikap, dukungan suami, dan kontrol perilaku tidak mempunyai hubungan yang signifikan dengan perilaku KADARZI. Pengetahuan dan niat ibu melakukan KADARZI mempunyai hubungan yang signifikan dengan perilaku KADARZI.
\end{abstract}

Kata kunci: Keluarga sadar gizi, perilaku KADARZI, balita gizi kurang, pengetahuan, niat. 


\section{PENDAHULUAN}

Pada masa balita dalam tumbuh kembang anak akan terjadi pertumbuhan dasar yang akan memengaruhi perkembangan di masa mendatang. Perkembangan anak membutuhkan interaksi sosial yang sesuai dengan kebutuhan pada setiap tahap perkembangannya (Adriani dan Wirjatmadi, 2012). Lingkungan sosial terdekat dibutuhkan untuk membentuk kepribadian anak. Peran keluarga akan menentukan status gizi balita (Hariyadi dan Ekayanti, 2011).

Masalah gizi kurang di Indonesia masih tinggi. Pada tahun 2013 hasil Riskesdas menunjukkan bahwa prevalensi gizi kurang di Indonesia sebesar 13,9\% (Kemenkes, 2013). Pada tahun 2015 provinsi Jawa Timur memiliki prevalensi gizi kurang sebesar 5,0\% dan Kota Surabaya memiliki prevalensi gizi kurang sebesar 4,26\%. Sedangkan di Puskesmas Sidotopo pada tahun 2015 memiliki prevalensi gizi kurang sebesar 26,51\% (Dinkes Prov. Jatim, 2015). Pada tahun 2016 angka tersebut meningkat menjadi 28,8\% (Puskesmas Sidotopo, 2016).

Salah satu faktor penyebab rendahnya perilaku kesehatan masyarakat yaitu pengetahuan dan sikap masyarakat yang kurang (Notoatmodjo, 2007). Peran ibu di dalam keluarga sangat memengaruhi dalam menyiapkan makanan. Sehingga pengetahuan ibu sangat diperlukan untuk memperbaiki gizi anggota keluarganya (Adriani dan Wirjatmadi, 2012). Hal ini sesuai dengan penelitian Karolina et al . (2012) bahwa ada hubungan antara pengetahuan gizi ibu dengan status gizi anak balita di Kabupaten Gayo Luwes.

Pengetahuan ibu tentang gizi, cara pemberian makan pada balita, dan jadwal pemberian makan anak balita sangat berperan dalam menentukan status gizi anak (Dahlia dan Ruslianti, 2008). Perilaku Keluarga Sadar Gizi (KADARZI) merupakan tindakan dalam menerapkan kelima indikator yaitu menimbangkan berat badan setiap bulan, memberikan ASI Eksklusif kepada bayi/balita, mengonsumsi makanan beranekaragam, menggunakan garam beryodium, dan mengonsumsi suplemen gizi (Octaviani dan Margawati, 2012). Perilaku ibu dalam menerapkan lima indikator KADARZI akan dipengaruhi oleh niat, sedangkan niat akan dipengaruhi oleh sikap ibu tentang KADARZI, dukungan anggota keluarga atau lingkungan terdekat, dan persepsi ibu mengenai KADARZI (Ajzen, 1988).

Pengetahuan KADARZI merupakan salah satu faktor penting yang harus dimiliki ibu balita sebagai orang yang berperan dalam persiapan makanan pada keluarga. Pengetahuan KADARZI yang baik menyebabkan ibu mampu menyusun menu yang baik untuk dikonsumsi. Semakin baik pengetahuan KADARZI maka ibu akan semakin memperhitungkan jenis dan jumlah makanan untuk dikonsumsi (Muctadi, 2006).

Pada tahun 2015 Provinsi Jawa Timur memiliki prevalensi KADARZI sebesar 86,6\% (Bappenas, 2015), sedangkan di Kota Surabaya memiliki prevalensi KADARZI sebesar 91,89\% (Dinkes Prov. Jatim, 2015). Namun di Puskesmas Sidotopo memiliki prevalensi KADARZI sebesar 75,91\% (Dinkes Prov. Jatim, 2015), dan pada tahun 2016 angka tersebut menurun menjadi 75,85\% (Puskesmas Sidotopo, 2016). Prevalensi tersebut masih di bawah target nasional yaitu 80\% (Bappenas, 2015).

Berdasarkan uraian di atas, peneliti tertarik untuk mengkaji lebih lanjut mengenai hubungan pengetahuan dan niat ibu dengan perilaku Keluarga Sadar Gizi (KADARZI) Ibu balita gizi kurang. Tujuan penelitian ini adalah untuk mengetahui hubungan pengetahuan, sikap, dukungan suami, kontrol perilaku, dan niat ibu dengan perilaku KADARZI ibu balita gizi kurang di Kelurahan Sidotopo Kecamatan Semampir Kota Surabaya. 


\section{METODE PENELITIAN}

Penelitian ini merupakan penelitian analitik observasional dengan menggunakan desain cross sectional. Penelitian ini dilakukan di Kelurahan Sidotopo, Kecamatan Semampir, Kota Surabaya pada bulan Juni sampai dengan Juli 2017. Subjek dalam penelitian ini adalah ibu yang memiliki balita gizi kurang di wilayah Kelurahan Sidotopo. Besar sampel diperoleh sebanyak 58 responden dengan cara pemilihan sampel yaitu acak sederhana (simple random sampling). Pengumpulan data pada penelitian ini dilakukan dengan wawancara menggunakan kuesioner.

Variabel dependent yaitu perilaku KADARZI, sedangkan variabel independent yaitu pendapatan keluarga, pengetahuan ibu, sikap ibu, dukungan suami ibu (subjective norm), kontrol perilaku ibu (perceived behavioral control), dan niat ibu melakukan KADARZI. Selain itu data yang diambil dalam penelitian ini yaitu karakteristik anak yang terdiri dari jenis kelamin dan usia balita, sedangkan karakteristik ibu balita yang terdiri dari usia ibu, pendidikan ibu, dan pendapatan keluarga.

Pengetahuan diukur menggunakan 20 pertanyaan dengan score pengetahuan dikategorikan menjadi kurang (< $60 \%)$, sedang $(60 \%-80 \%)$, dan baik (> $80 \%$ ) (Khomsan, 2000). Sikap diukur menggunakan 10 pertanyaan dengan range score 1-70 menggunakan skala theory of planned behavior 1-7 dari sangat tidak setuju sampai sangat setuju (Francis et al , 2004). Dukungan suami diukur menggunakan 10 pertanyaan dengan range score $1-70$ menggunakan skala theory of planned behavior 1-7 dari sangat tidak setuju sampai sangat setuju (Francis et al ., 2004). Kontrol perilaku diukur menggunakan 12 pertanyaan dengan range score 1-84 menggunakan skala theory of planned behavior 1-7 dari sangat tidak setuju sampai sangat setuju (Francis et al ., 2004). Niat diukur menggunakan 11 pertanyaan dengan range score 1-77 menggunakan skala theory of planned behavior 1-7 dari sangat tidak setuju sampai sangat setuju (Francis et al ., 2004). Perilaku KADARZI memiliki diukur menggunakan 5 pertanyaan dengan range score $1-5$, jika score 5 artinya KADARZI dan jika score $<$ 5 artinya TIDAK KADARZI (Depkes RI, 2008). Pada penelitian ini, karakteristik balita yaitu jenis kelamin menggunakan skala data nominal dan usia balita menggunakan skala data rasio didistribusikan dengan quintil. Karakteristik ibu balita yaitu usia ibu dan pendapatan keluarga menggunakan skala data rasio didistribusikan dengan quintil, sedangkan pendidikan ibu menggunakan skala data ordinal.

Analisis data terdiri dari analisis univariat dan analisis bivariat. Analisis univariat untuk menggambarkan distribusi frekuensi dari variabel yang diteliti. Analisis bivariat untuk mengetahui hubungan antara variabel independent dan dependent dengan menggunakan uji pearson correlation, jika $\mathrm{p}<0,05$ maka terdapat hubungan antara kedua variabel.

\section{HASIL}

Karakteristik responden dalam penelitian ini meliputi karakteristik balita yaitu jenis kelamin dan usia balita, sedangkan karakteristik ibu balita meliputi usia ibu, pendidikan, dan pendapatan keluarga dapat dilihat pada tabel 1 .

Penelitian ini diambil dari 58 balita yang mempunyai status gizi kurang dan sebagian besar memiliki jenis kelamin perempuan. Berdasarkan data Puskesmas Sidotopo, di Kelurahan Sidotopo mempunyai proporsi balita berjenis kelamin perempuan lebih banyak dibandingkan balita laki-laki.

Balita yang berusia di bawah 24 bulan rutin datang mengikuti penimbangan di Posyandu. Hal ini dikarenakan balita masih dalam tahap imunisasi lengkap. Sebagian besar balita berusia di atas 24 bulan tidak rutin mengikuti penimbangan di Posyandu dengan alasan balita sedang tidur atau 
keluarga balita sedang bepergian sehingga pertumbuhan dan perkembangan balita tidak terpantau.

Tabel 1. Karakteristik Responden

\begin{tabular}{lcc}
\hline \multicolumn{1}{c}{ Variabel } & n & \% \\
\hline Jenis Kelamin & & \\
Laki-laki & 21 & 36,2 \\
Perempuan & 37 & 63,8 \\
\hline Usia Balita (Bulan) & & \\
10-14 & 7 & 12 \\
$15-18$ & 8 & 13,7 \\
$19-24$ & 6 & 10,3 \\
$25-27$ & 6 & 10,3 \\
$28-58$ & 31 & 53,7 \\
\hline Usia Ibu (Tahun) & & \\
19-22 & 7 & 12 \\
$23-24$ & 8 & 13,8 \\
$25-27$ & 6 & 10,3 \\
$28-30$ & 7 & 12,1 \\
$31-42$ & 30 & 51,8 \\
\hline Pendidikan Ibu & & \\
SD & 11 & 19 \\
SMP & 26 & 44,8 \\
SMA & 21 & 36,2 \\
\hline Pendapatan Keluarga & & \\
$500.000-750.000$ & 7 & 12 \\
$>750.000-1.000 .000$ & 15 & 25,8 \\
$>1.000 .000-1.250 .000$ & 5 & 8,6 \\
$>1.250 .000-3.300 .000$ & 31 & 53,6 \\
\hline
\end{tabular}

Responden dalam penelitian ini yaitu ibu balita gizi kurang. Ibu balita yang berusia produktif lebih sering datang ke Posyandu daripada ibu balita yang berusia muda. Ibu balita yang berusia produktif lebih matang dalam pembentukan pola asuh anak yang akan berpengaruh terhadap status gizi.

Pendidikan merupakan salah satu poin penting dalam kehidupan terutama pendidikan kesehatan. Pendidikan ibu balita gizi kurang di Kelurahan Sidotopo tergolong rendah. Pendidikan gizi yang diperoleh ibu balita berasal dari petugas kesehatan dan kader Posyandu. Semakin tinggi pendidikan ibu, maka semakin mudah ibu balita menyerap informasi-informasi kesehatan.

Dapat diketahui bahwa pendapatan keluarga balita gizi kurang per kapita/ bulan berkisar antara $\mathrm{Rp} 500.000,00$ sampai dengan $\mathrm{Rp} 3.300 .000,00$ dengan ratarata $\mathrm{Rp} 1.347 .413,79$. Sebagian besar mata pencaharian suami sebagai buruh, sedangkan sebagian besar ibu balita tidak bekerja. Ibu balita yang tidak memiliki aktivitas di luar rumah tentunya mempunyai kesempatan yang lebih besar dalam pengasuhan anaknya. Pendapatan yang rendah menyebabkan daya beli yang rendah sehingga tidak mampu untuk membeli pangan yang beraneka ragam.

Rata-rata perilaku KADARZI pada ibu yang memiliki balita gizi kurang di Kelurahan Sidotopo sebesar 3,7. Dari lima indikator KADARZI, keluarga balita yang

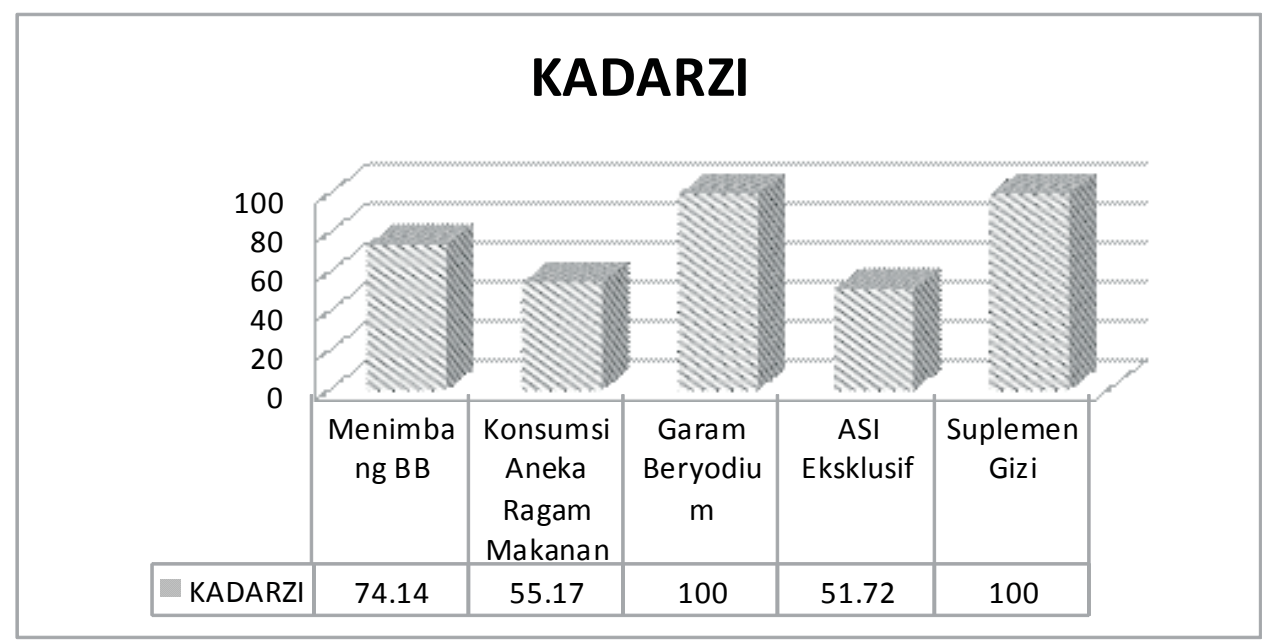

Gambar 1. Presentase Indikator KADARZI 
menimbang berat badan di Posyandu setiap bulan (74,14\%), keluarga yang mengonsumsi aneka ragam makanan (55,17\%), keluarga yang menggunakan garam beryodium $(100,0 \%)$, ibu yang memberikan ASI eksklusif pada balita $(51,72 \%)$, dan balita yang mengonsumsi suplemen gizi (100,0\%). Pemberian ASI eksklusif dan konsumsi aneka ragam makanan sebagian ibu balita sulit untuk menerapkan. Pada umumnya, ibu balita mengetahui lama pemberian ASI eksklusif sekurang-kurangnya 6 bulan, namun sebagian ibu balita memberikan makanan selain ASI kepada bayi terlalu dini dengan alasan ASI sedikit keluar dan faktor sosial budaya. Selain itu ibu balita tidak menyediakan makanan beragam dikarenakan pendapatan keluarga yang rendah. Namun sebagian ibu mengatakan bahwa anak susah makan atau bahkan tidak mau makan.

Untuk melakukan penimbangan di Posyandu (D/S) keikutsertaan ibu balita kurang, angka tersebut masih di bawah target nasional yaitu 85\% (Dinkes Kota Surabaya, 2015). Penggunaan garam beryodium pada ibu balita sudah baik, namun ibu tidak mengetahui cara penyimpanan dan penggunaan dari garam beryodium karena banyak terjual di toko-toko sekitar rumah. Seluruh balita di Kelurahan Sidotopo rutin mendapatkan vitamin A pada bulan Februari dan Agustus, hal itu dikarenakan kader Posyandu yang memberikan langsung kepada balita melalui kunjungan rumah. Angka tersebut sesuai dengan target nasional yaitu 100\% (Dinkes Kota Surabaya, 2015).

Ibu yang mempunyai usia yang cukup, maka tingkat kematangan dalam hal menyerap pendidikan kesehatan akan lebih baik. Rata-rata usia ibu balita gizi kurang sebesar 30,8. Perubahan usia dapat menggambarkan kematangan seseorang, dalam hal kemauan ibu berperilaku KADARZI.

Pendapatan keluarga digunakan untuk memenuhi salah satu indikator KADARZI yaitu mengonsumsi makanan beraneka ragam. Rata-rata pendapatan keluarga balita gizi kurang sebesar 1347413,7. Sebagian besar suami ibu balita bekerja sebagai buruh. Sedangkan, sebagian besar ibu balita adalah ibu rumah tangga. Ibu balita tidak bekerja dengan alasan rendahnya pendidikan ibu sehingga sulit untuk mendapatkan lapangan pekerjaan.

\section{PENGETAHUAN}

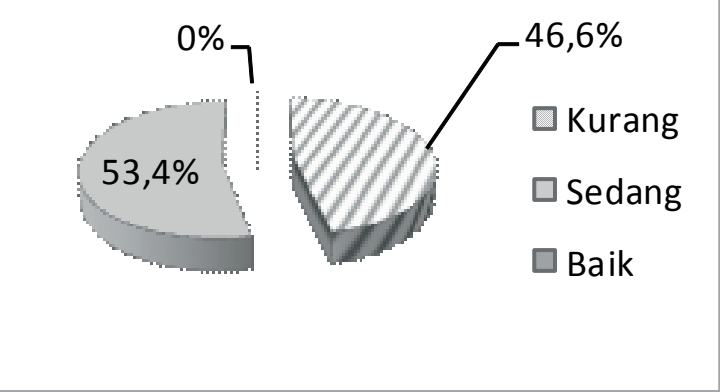

Gambar 2. Presentase Pengetahuan

Pengetahuan KADARZI ibu balita menjadi salah satu faktor penting yang harus dimiliki ibu balita sebagai orang yang berperan dalam persiapan makanan keluarga. Rata-rata pengetahuan ibu balita gizi kurang sebesar 58,01. Sebagian besar ibu balita memiliki pengetahuan yaitu dalam kategori sedang. Pengetahuan ibu yang rendah disebabkan karena ibu balita tidak rutin datang ke Posyandu. Pengetahuan gizi ibu balita diperoleh melalui penyuluhan kesehatan yang dilakukan petugas kesehatan atau kader Posyandu. Penyuluhan kesehatan dilakukan setiap bulan di Posyandu yang dihadiri oleh ibu balita dan kader Posyandu. Di dalam keluarga, ibu berperan mempersiapkan makanan. Pengetahuan ibu tentang gizi sangat diperlukan dalam peningkatan status gizi anggota keluarganya. Pengetahuan dan keterampilan ibu dalam mempersiapkan makanan sangat diharapkan untuk memperbaiki status gizi anggota keluarganya.

Sikap ibu mengenai KADARZI merupakan perasaan yang mendukung atau memihak maupun perasaan tidak mendukung atau tidak memihak terhadap 
Tabel 2. Hasil Uji Pearson Correlation

\begin{tabular}{lccccc}
\hline \multicolumn{1}{c}{ Variabel } & N & Mean & SD & Pearson Correlation & p-value \\
\hline Perilaku KADARZI & 58 & 3,7 & 1,2 & - & - \\
Usia Ibu & 58 & 30,8 & 6,713 & 0,026 & 0,845 \\
Pendapatan & 58 & 1347413,7 & 568810,8 & 0,271 & 0,040 \\
Pengetahuan & 58 & 58,01 & 13,2 & 0,212 & 0,033 \\
Sikap & 58 & 43,7 & 5,2 & $-0,022$ & 0,871 \\
Subjective Norm & 58 & 35,9 & 7,6 & $-0,024$ & 0,861 \\
Perceived Behavioral & 58 & 56,5 & 5,02 & 0,191 & 0,150 \\
Control & & & & & \\
Niat & 58 & 48,05 & 4,4 & 0,245 & 0,048 \\
\hline
\end{tabular}

perilaku KADARZI. Rata-rata sikap ibu balita gizi kurang mengenai KADARZI sebesar 43,7. Ibu yang memiliki sikap yang baik lebih memerhatikan kesehatan keluarga terutama anak balita.

Dukungan anggota keluarga sangat diperlukan untuk memengaruhi kontrol perilaku seseorang untuk menunjukkan atau tidak menunjukkan perilaku mereka. Dukungan suami (subjective norm) ibu balita mengenai KADARZI lebih banyak pada indikator konsumsi makanan yang beragam. Suami ibu lebih banyak yang menyarankan untuk mengonsumsi makanan yang seimbang untuk keluarga dan balitanya. Sedangkan untuk indikator KADARZI yang lain sebagian suami ibu tidak memberikan dukungan kepada ibu balita dengan alasan tidak mengetahui.

Kontrol perilaku (perceived behavioral control) ibu balita gizi kurang memiliki rata-rata sebesar 56,5. Semakin baik kontrol perilaku ibu mengenai KADARZI maka akan semakin baik pula perilaku KADARZI ibu. Sebagian besar ibu balita gizi kurang mengetahui pentingnya berperilaku KADARZI karena mendapatkan pendidikan gizi dari petugas kesehatan, namun kemauan ibu balita dalam menerapkannya masih kurang.

Niat ibu balita dalam melakukan KADARZI memiliki rata-rata sebesar 48,05. Semakin lama ibu memiliki niat dalam melakukan KADARZI maka semakin besar kecenderungan perubahan perilaku KADARZI ibu. Sebagian besar ibu balita tidak memiliki pengetahuan yang baik mengenai KADARZI, ibu balita tidak mendapatkan dukungan dari suami mengenai penerapan indikator KADARZI, sikap dan kontrol perilaku ibu yang kurang mengenai KADARZI menyebabkan niat ibu untuk melakukan KADARZI rendah.

Pendapatan keluarga $(\mathrm{p}=0,040)$, pengetahuan ibu mengenai KADARZI ( $p=$ 0,033) dan niat ibu melakukan KADARZI $(0,048)$ mempunyai hubungan yang signifikan dengan perilaku KADARZI ibu balita gizi kurang.

Sikap ibu mengenai KADARZI ( $\mathrm{p}=$ 0,871 ), dukungan suami (subjective norm) ibu tentang KADARZI $(\mathrm{p}=0,861)$, dan kontrol perilaku (perceived behavioral control) ibu mengenai KADARZI $(\mathrm{p}=0,150)$ tidak mempunyai hubungan yang signifikan dengan perilaku KADARZI ibu balita gizi kurang.

Hasil uji statistika menggunakan uji pearson correlation antara variabel dependent dengan variabel independent dapat dilihat pada tabel 2 .

\section{PEMBAHASAN}

Keluarga Sadar Gizi (KADARZI) merupakan sikap dan perilaku keluarga yang dapat mencerminkan keadaan gizi yang baik yaitu mengonsumsi makanan beraneka ragam dan bergizi seimbang (Arisman, 
2010). Menurut Supariasa et al . (2013) bahwa status KADARZI didasarkan melalui lima indikator yaitu menimbang berat badan balita secara teratur, memberikan ASI Eksklusif pada bayi dan balita sekurang-kurangnya 0-6 bulan, menggunakan garam beryodium, mengonsumsi makanan beraneka ragam, dan mengonsumsi suplemen gizi.

Berdasarkan hasil penelitian Keluarga Sadar Gizi (KADARZI) di Kelurahan Sidotopo sebagian besar balita berjenis kelamin perempuan $(63,8 \%)$, dengan usia paling banyak berkisar 28-58 bulan. Usia ibu balita sebagian besar berkisar 31-42 tahun, pendidikan ibu mayoritas adalah tamat SMP (44,8\%). Menurut penelitian Rahmawati (2006) bahwa ibu yang memiliki pendidikan tinggi akan lebih mudah menerima pesan serta informasi gizi dan kesehatan untuk balita. Menurut penelitian Fatma (2010) tentang Pengetahuan dan Praktek Keluarga Sadar Gizi Ibu Balita bahwa dengan tingkat pendidikan yang rendah, responden akan sulit menerima informasi-informasi gizi dan kesehatan untuk dipraktikkan dalam kehidupan sehari-hari.

Berdasarkan hasil penelitian dari lima indikator KADARZI bahwa terdapat masalah mengenai kurangnya kesadaran ibu dalam memberikan ASI Eksklusif kepada bayi/ balita dengan alasan ASI sedikit keluar dan sosial budaya di masyarakat, dan kurangnya kesadaran ibu untuk menyediakan makanan yang beragam untuk keluarga.

Ibu yang memiliki pengetahuan kurang sebanyak 27 orang $(46,6 \%)$ dan pengetahuan yang sedang sebanyak 31 orang $(53,4 \%)$. Pemilihan pengolahan pangan serta cara pemberian makanan yang sehat dan bergizi untuk balita diperlukan pengetahuan dan pendidikan ibu yang tinggi. Pemahaman mengenai pentingnya gizi dan kesehatan dapat lebih mudah diterima oleh ibu yang memiliki pendidikan tinggi. Sebagian besar ibu balita gizi kurang di Kelurahan Sidotopo memiliki pendidikan akhir tamat SMP. Pengetahuan ibu yang rendah disebabkan karena kurangnya informasi yang dapat diserap responden karena tingkat pendidikan ibu yang rendah yaitu tamat SMP. Sebaliknya jika pendidikan ibu tinggi maka semakin baik pengetahuan gizi ibu, ibu yang berpendidikan tinggi cenderung mudah mengerti dan memahami informasi yang diberikan.

Berdasarkan hasil uji statistika pendapatan keluarga berhubungan dengan perilaku KADARZI $(\mathrm{p}=0,040)$. Hal ini sejalan dengan penelitian Kadir dan Pakaya (2015) bahwa faktor yang memengaruhi penerapan perilaku KADARZI adalah pendapatan keluarga. Dengan kata lain semakin tinggi pendapatan keluarga maka semakin besar pula persentase penghasilan tersebut untuk membeli bahan makanan beragam. Keluarga dengan pendapatan terbatas kemungkinan besar kurang dapat memenuhi kebutuhan makanan terutama untuk memenuhi kebutuhan zat gizi anggota keluarganya (Fikawati dan Shafiq, 2012). Menurut Oktaviani dan Margawati (2012) pendapatan keluarga ikut memengaruhi KADARZI, hal ini karena salah satu indikator KADARZI adalah mengonsumsi aneka ragam makanan yang erat kaitannya dengan kebutuhan pangan yang juga dipengaruhi oleh pendapatan.

Pengetahuan KADARZI merupakan salah satu faktor penting yang harus dimiliki ibu balita sebagai orang yang berperan dalam persipan makanan pada keluarga. Pengetahuan KADARZI yang baik menyebabkan ibu mampu menyusun menu yang baik untuk dikonsumsi. Semakin baik pengetahuan KADARZI maka ibu akan semakin memperhitungkan jenis dan jumlah makanan untuk dikonsumsi (Muctadi, 2006).

Pengetahuan ibu balita gizi kurang di Kelurahan Sidotopo masih rendah, hal ini disebabkan karena mayoritas pendidikan akhir ibu balita gizi kurang merupakan tamat SMP. Menurut Notoatmodjo (2012) pendidikan memengaruhi proses belajar seseorang, semakin tinggi pendidikan maka semakin mudah seseorang untuk 
menerima informasi. Hal ini sejalan dengan penelitian Alfiasari dan Hastuti (2010) bahwa pengetahuan ibu dipengaruhi oleh pendidikan ibu. Hasil penelitian Oktaviani dan Margawati (2012) tentang Hubungan Pengetahuan dan Perilaku Ibu Buruh Pabrik tentang KADARZI dengan Status Gizi Anak Balita di Kelurahan Pagersari dengan hasil penelitian terdapat hubungan antara pengetahuan dengan status gizi balita $(\mathrm{p}=0,005<\alpha=0,05)$.

Hasil uji statistika pengetahuan ibu balita tentang KADARZI memiliki hubungan yang signifikan dengan perilaku KADARZI $(\mathrm{p}=0,033)$. Hal ini sejalan dengan teori Notoatmodjo (2010) bahwa pengetahuan dapat diperoleh dari pengalaman seseorang dan informasi yang bersumber dari media massa, buku, maupun tenaga kesehatan.

Pengetahuan merupakan salah satu faktor penentu perilaku kesehatan. Menurut penelitian Arbella et al . (2013) bahwa terdapat hubungan antara pengetahuan ibu tentang KADARZI dengan perilaku KADARZI $(p=0,001)$. Semakin tinggi pengetahuan responden maka semakin besar kemungkinan untuk melaksanakan indikator KADARZI, sebaliknya semakin rendah pengetahuan responden maka semakin kecil untuk menerapkan indikator KADARZI $(\mathrm{r}=0,390 ; \mathrm{p}<0,05)$ (Setiyaningsih, 2007). Perilaku yang didasari oleh pengetahuan akan lebih bertahan daripada perilaku yang tidak didasari oleh pengetahuan (Azwar, 2003). Hasil penelitian Suyahmi (2011) menunjukkan bahwa terdapat hubungan antara pengetahuan tentang keluarga mandiri sadar gizi dengan perilaku sadar gizi dengan kategori rendah $(r=0,242 ; p=0,049)$.

Makanan yang beragam yaitu makanan yang mengandung unsur zat gizi yang diperlukan oleh tubuh. Mengonsumsi aneka ragam makanan diperlukan untuk memenuhi kecukupan sumber tenaga, pembangun, dan pengatur (Sulistyoningsih, 2012). Dengan mengonsumsi aneka ragam makanan maka kekurangan zat gizi akan dilengkapi oleh jenis makanan lain, sehingga diperoleh masukan gizi yang seimbang (Francin dan Paath, 2005).

Perilaku KADARZI merupakan suatu tindakan dalam menerapkan lima indikator KADARZI. Perilaku KADARZI terdorong berdasarkan niat seseorang, dan terbentuknya niat seseorang ditentukan oleh sikap terhadap perilaku KADARZI tersebut. Sikap seseorang dipengaruhi oleh faktor internal yaitu faktor psikologis dan faktor eksternal yaitu intervensi yang diperoleh dari individu lain seperti pendidikan, pelatihan, dan penyuluhan (Walgito, 1994).

Menurut Azwar (2003), faktor yang sangat berpengaruh terhadap perubahan perilaku adalah faktor eksternal yang diperoleh dari luar individu dan sadar atau tidak seseorang dalam menghadapi sikapsikap tertentu. Sikap seseorang ditentukan oleh tiga komponen yaitu kepercayaan atau keyakinan, ide dan konsep terhadap suatu objek, emosional terhadap suatu objek, dan kecenderungan untuk bertindak (trend to be have) (Notoatmodjo, 2007).

Sikap ibu balita mengenai KADARZI memiliki rata-rata sebesar 43,7. Berdasarkan hasil uji statistika sikap ibu tentang KADARZI tidak berhubungan dengan perilaku KADARZI $(\mathrm{p}=0,871)$. Hal ini sejalan dengan penelitian Septian dan Helmy (2013) bahwa tidak ada hubungan antara sikap keluarga dengan perilaku KADARZI $(p>0,05)$. Selain itu sama halnya dengan penelitian Hartatik (2009) bahwa tidak ada hubungan yang bermakna antar sikap ibu tentang ASI dengan pemberian ASI Eksklusif di Kelurahan Gunungpati Kecamatan Gunungpati. Berbeda dengan hasil penelitian Wowor et al . (2013) tentang Hubungan Pengetahuan dan Sikap dengan Pemberian ASI Eksklusif pada Ibu Menyusui di Puskesmas Bahu Kota Manado bahwa terdapat hubungan antara sikap dengan pemberian ASI Eksklusif pada ibu menyusui. Sikap yang kurang terhadap pemberian ASI Eksklusif disebabkan karena pengaruh 
lingkungan sekitar, dimana lingkungan sekitar sangat memengaruhi seseorang untuk mengambil keputusan.

Menurut Effendi dan Tjahjono (2000) bahwa dukungan suami merupakan upaya yang diberikan suami baik secara fisik, mental, maupun sosial. Hasil penelitian Marlina (2014) mengenai Hubungan Dukungan Suami dengan Perilaku Istri Melakukan Pemeriksaan Pap Smear di Puskesmas Umbulharjo II Kota Yogyakarta Tahun 2014. diperoleh hubungan yang signifikan dengan $\mathrm{p}$-value $0,01(\mathrm{p}<0,05)$ menunjukkan bahwa dukungan suami yang kurang yaitu dukungan informasi yang berupa ikut memberikan informasi, petunjukpetunjuk, dan nasehat terkait pemeriksaan pap smear. Dukungan suami ini dibutuhkan untuk faktor pendukung yang berpengaruh terhadap perubahan perilaku istri.

Dukungan suami (subjective norm) ibu tentang KADARZI memiliki rata-rata sebesar 35,9. Berdasarkan hasil uji statistik dukungan suami ibu tidak berhubungan dengan perilaku KADARZI $(\mathrm{p}=0,861)$. Kondisi ini menunjukkan bahwa peran dukungan suami terhadap perilaku KADARZI ibu masih kurang. Hal ini sejalan dengan penelitian Sartono dan Utaminingrum (2012) menunjukkan bahwa dukungan suami tidak berhubungan dengan praktek pemberian ASI Eksklusif $(p=1,000)$. Tetapi berbeda dengan penelitian Rubinem (2012) bahwa ada hubungan yang bermakna antara ibu yang mendapatkan dukungan keluarga baik dan dukungan keluarga kurang dengan pemberian ASI Eksklusif $(p<0,05)$.

Menurut penelitian Trisnawati (2011) tentang Hubungan Persepsi Ibu tentang Posyandu dengan Perilaku Kunjungan Balita Ke Posyandu Mawar di Dusun Soragan Ngestiharjo Kasihan Bantul Yogyakarta diperoleh hubungan antara persepsi ibu dengan perilaku kunjungan ibu ke posyandu, menjelaskan bahwa ibu balita yang memiliki persepsi yang tidak baik tentang Posyandu faktor yang memengaruhi yaitu tingkat sosial responden.
Kontrol perilaku (perceived behavioral control) ibu tentang KADARZI memiliki rata-rata sebesar 56,5. Berdasarkan hasil uji statistik persepsi ibu tidak berhubungan dengan perilaku KADARZI $(p=0,150)$. Hal ini tidak sejalan dengan penelitian Maryani (2012) bahwa seseorang semakin merasa bahwa dirinya berisiko terhadap suatu penyakit maka tindakan pencegahan yang dilakukan akan semakin baik pula. Jadi dapat diartikan bahwa semakin baik persepsi ibu mengenai KADARZI maka akan berpengaruh terhadap perilaku KADARZI.

Dalam penelitian Jatmika et al . (2014) tentang Dukungan Tenaga Kesehatan Untuk Meningkatkan Niat Ibu Hamil Dalam Memberikan ASI Eksklusif di Wilayah Kerja Puskesmas Gondokusuman Kota Yogyakarta, bahwa responden yang memiliki sikap negatif akan cenderung memiliki niat rendah dalam pemberian ASI Eksklusif.

Niat ibu dalam melakukan KADARZI memiliki rata-rata sebesar 48,05. Berdasarkan hasil uji statistika niat ibu dalam melakukan KADARZI memiliki hubungan yang signifikan dengan perilaku KADARZI $(p=0,048)$. Menurut teori Fishbein dan Ajzen (1975) bahwa niat melakukan atau tidak suatu perilaku dipengaruhi oleh dua penentu dasar, yaitu sikap, pengaruh sosial, dan norma subjektif.

Kelebihan dari penelitian ini adalah kejadian gizi kurang masih tinggi dan prevalensi KADARZI di Kelurahan Sidotopo belum mencapai target nasional yaitu $80 \%$, sehingga diperlukan penelitian publikasi untuk menarik penelitian lain agar dapat mengembangkan penelitian. Kekurangan dari penelitian ini adalah tidak ditelitinya faktor langsung dan tidak langsung yang berhubungan dengan status gizi balita seperti penyakit infeksi dan pola asuh anak serta PHBS keluarga.

\section{SIMPULAN}

Pendapatan keluarga, pengetahuan dan niat memiliki hubungan yang signifikan dengan perilaku KADARZI ibu balita gizi 
kurang, sementara sikap, dukungan suami (subjective norm), dan kontrol perilaku (perceived behavioral control) menunjukkan hubungan yang tidak signifikan.

Oleh karena itu, diperlukan peningkatan pengetahuan ibu balita gizi kurang dengan memberikan pendidikan Keluarga Sadar Gizi (KADARZI) menggunakan media leaflet untuk meningkatkan sikap, dukungan suami (subjective norm), kontrol perilaku (perceived behavioral control), dan niat sehingga perilaku KADARZI ibu balita gizi kurang meningkat.

\section{DAFTAR PUSTAKA}

Adriani, M, dan Wirjatmadi, B., 2012. Peranan Gizi dalam Siklus Kehidupan. Jakarta: Kencana Prenada Media Group. Alfiasari, C., dan Hastuti, D., 2010. Nilai Anak, Stimulasi Psikososial, dan Perkembangan Kognitif Anak Usia 2-5 Tahun Pada Keluarga Rawan Pangan di Kabupaten Banjarnegara Jawa Tengah. Jurnal Ilmu Kesehatan vol.3 no.1 Januari 2010 hal. 27-34.

Arbella, V.M., Erna, W., dan Rahayu, S., 2013. Hubungan Pengetahuan dan Sikap Ibu tentang Keluarga Sadar Gizi dengen Perilaku Sadar Gizi Keluarga Balita di Desa Karangsono Kecamatan Kwadungan Kabupaten Ngawi Tahun 2013. Jurnal Kebidanan vol. 2 no. 5 Oktober 2013. Hal 47-56.

Arisman, 2010. Gizi Dalam Daur Kehidupan. Jakarta: EGC.

Ajzen, I., 1988. From Intentions to Actions: Attitude, Personality, \& Behavior. Dorsey Press Chicago, tersedia di (http://www. niu.edu/user/tj0bjs1/psyc624/Ajzen\%20 Driver\%20(1992).pdf), [Diakses tanggal 10 Januari 2017].

Azwar, S., 2003. Sikap Manusia, Teori dan Pengukurannya. Yogyakarta: Pustaka Pelajar.

Badan Penelitian dan Pengembangan Kesehatan Kementerian Kesehatan Republik Indonesia, 2013. Riset Kesehatan Dasar Tahun 2013, tersedia di: <http:// www.depkes.go.id.> , diakses tanggal 11 September 2017].

Dahlia, M., dan Ruslianti, 2008. Menu Sehat untuk Kecerdasan Balita. Jakarta: Agromedia.

Departemen Kesehatan RI, 2008. Pedoman Pemantauan Status Gizi (PSG) dan Keluarga Sadar Gizi (Kadarzi). Jakarta.

Dinas Kesehatan Kota Surabaya, 2015. Laporan Bulanan Dinas Kesehatan Kota Surabaya Tahun 2015. Surabaya.

Dinas Kesehatan Provinsi Jawa Timur, 2015. Laporan Bulanan Dinas Kesehatan Provinsi jawa Timur Tahun 2015. Surabaya.

Badan Perencanaan Pembangunan Nasional (BAPPENAS), 2015. Rencana Pembangunan Jangka Menengah Nasional (RPJMN) 2015-2019 Bidang Kesehatan. Tersedia di: <http://www.depkes.go.id/ resources/download/rakerkesnas-2015/ reg-barat/Paparan\%20Bappenas.pdf.> [Diakses tanggal 12 Januari 2017].

Effendi, R.W., dan Tjahjono, E., 2000. Hubungan Antara Perilaku Coping dan Dukungan Sosial dengan Kecemasan Pada Ibu Hamil Anak Pertama. Jurnal Anima, 14, hal 214-227.

Fatma, 2010. Pengetahuan dan Praktek Keluarga Sadar Gizi Ibu Balita. Jurnal Gizi Kesehatan Masyarakat Nasional vol. 4 no. 4 Februari 2010 hal. 162-171.

Fikawati, S., dan Shafiq, A., 2012. Buku Panduan Sistem Pusat Karir. Jakarta: Dikti.

Fishbein, M., dan Ajzen, I., 1975. Belief, Attitude, Intention, and Behavior: An Introduction to Theory and Research. Addison-Wesley.

Francin, E., dan Paath, 2005. Gizi Dalam Kesehatan Reproduksi. Jakarta: EGC.

Francis, J., Eccles, J., Martin, P., Marie, A.W., 2004. Constructing Questionnaires Based in the Theory of Planned Behavior, A Manual for Health Services Researchers. Centre for Health Services Research University of Newcastle May 2004. Tersedia di: http://web.fkm.edu.rs/files/ 
blogs/2010-11/Psihologija/Socijalna/ TPB.pdf. [Diakses pada tanggal 15 Maret 2017].

Hariyadi, D., dan Ekayanti, I., 2011. Analisis Pengaruh Perilaku Keluarga Sadar Gizi terhadap Stunting di Propinsi Kalimantan Barat. Jurnal Teknologi dan Kejuruan vol. 34 no. 1 Pebruari 2011 hal. 71-80.

Hartatik, T., 2009. Hubungan Pengetahuan dan Sikap Ibu dengan Pemberian ASI Eksklusif di Kelurahan Gunungpati Kecamatan Gunungpati Kota Semarang Tahun 2009. Skripsi. Semarang: Universitas Negeri Semarang.

Jatmika, S.E.D., Shaluhiyah, Z., Suryoputro, A., 2014. Dukungan Tenaga Kesehatan Untuk Meningkatkan Niat Ibu Hamil Dalam Memberikan ASI Eksklusif di Wilayah Kerja Puskesmas Gondokusuman Kota Yogyakarta. Jurnal Promosi Kesehatan Indonesia vol. 9 no. 2 Agustus 2014 hal. 196-205.

Jogiyanto, 2007. Sistem Informasi Keperilakuan. Yogyakarta: Andi Offset.

Kadir, S., dan Pakaya, S., 2015. Pengaruh Penerapan Perilaku Keluarga Sadar Gizi (KADARZI) dengan Status Gizi Balita. UNG Press hal. 21-26.

Karolina, E.N., Ernawati, A., dan Evawany, Y., 2013. Hubungan Perilaku Kadarzi dengan Status Gizi Balita Usia 12-59 Bulan di Wilayah Kerja Puskesmas Blangkejeran Kecamatan Blangkejeran Kabupaten Gayo Lues Tahun 2012. Jurnal Gizi, Kesehatan Reproduksi dan Epidemiologi Vol. 2 No. 2 (2013) Hal.1-10.

Khomsan, A., 2000. Teknik Pengukuran Pengetahuan Gizi. Bogor: Jurusan Gizi Masyarakat dan Sumber Daya Keluarga IPB.

Marlina, E., 2014. Hubungan Dukungan Suami dengan Perilaku Istri Melakukan Pemeriksaan Pap Smear di Puskesmas Umbulharjo II Kota Yogyakarta Tahun 2014. Skripsi. Yogyakarta: STIK Aisyiyah Yogyakarta.

Maryani, L., 2012. Hubungan Komponen Health Belief Model (HBM) dengan
Penggunaan Kondom pada Anak Buah Kapal (ABK) di Pelabuhan Belawan, Epi Treat Unit-Universitas Sumatera Utara. Jurnal Precure vol. 1 no. 1 April 2013.

Muctadi, 2006. Prinsip Proses dan Teknologi Pangan. Bandung: Alfabeta.

Notoatmodjo, S., 2007. Pendidikan dan Perilaku Kesehatan. Jakarta: Rineka Cipta.

Notoatmodjo, S., 2010. Promosi Kesehatan Teori dan Aplikasi. Jakarta: Rineka Cipta.

Notoatmodjo, S., 2012. Metodologi Penelitian Kesehatan. Jakarta: Rineka Cipta.

Octaviani, I.A., dan Margawati, A., 2012. Hubungan Pengetahuan dan Perilaku Ibu Buruh Pabrik tentang KADARZI (Keluarga Sadar Gizi) dengan Status Gizi Anak Balita (Studi di Kelurahan Pagersari, Ungaran). Journal of Nutrition College vol. 1 no. 1 Tahun 2012 hal. 4654.

Puskesmas Sidotopo, 2016. Laporan Bulanan Puskesmas Sidotopo Tahun 2016. Surabaya.

Rahmawati, 2006. Status Gizi dan Perkembangan Anak Usia Dini di Taman Pendidikan Karakter Sutera Alam, Desa Sukamantri. Skripsi. Bogor: Institut Pertanian Bogor.

Rubinem, 2012. Faktor-Faktor yang Berhubungan dengan Perilaku Pemberian ASI Eksklusif di Puskesmas Srondol Kota Semarang Tahun 2012. Skripsi. Jakarta: Universitas Indonesia.

Sartono, A., dan Utaminingrum, H., 2012. Hubungan Pengetahuan Ibu, Pendidikan Ibu dan Dukungan Suami dengan Praktek Pemberian ASI Eksklusif di Kelurahan Muktiharjo Kidul Kecamatan Telogosari Kota Semarang. Jurnal Gizi Universitas Muhamadyah Semarang vol. 1 no. 1 November 2012 hal. 1-10.

Septian, D., dan Helmy, R., 2013. Pengetahuan dan Sikap Keluarga dengan Perilaku, Keluarga Sadar Gizi (KADARZI). Jurnal Keperawatan vol. IX no. 1 April 2013 hal. 49-56. 
Setiyaningsih, D., 2007. Hubungan antara Pengetahuan dan Sikap Ibu tentang Keluarga Mandiri Sadar Gizi (KADARZI) dengan Status KADARZI pada Keluarga Anak Usia 5-59 Bulan di Puskesmas Moyudan Kabupaten Sleman. Skripsi. Yogyakarta: Universitas Gajah Mada.

Suhardjo, 2008. Perencanaan Pangan dan Gizi. Jakarta: Bumi Aksara.

Sulistyoningsih, H., 2012. Gizi Untuk Kesehatan Ibu dan Anak. Yogyakarta: Graha Ilmu.

Supariasa, I.D.N., Bakri, B., Fajar, I., 2013. Penilaian Status Gizi. Jakarta: EGC.

Suyahmi, 2011. Hubungan Pengetahuan dan Sikap Ibu tentang Keluarga Mandiri Sadar Gizi (KADARZI) dengan Perilaku Sadar Gizi pada Keluarga Balita Usia
6-59 Bulan di Desa Buran Kecamatan Tasikmadu Kabupaten Karanganyar. Skripsi. Surakarta: Universitas Muhamadyah Surakarta.

Trisnawati, 2011. Hubungan Persepsi Ibu tentang Posyandu dengan Perilaku Kunjungan Balita Ke Posyandu Mawar di Dusun Soragan Ngestiharjo Kasihan Bantul Yogyakarta. Skripsi. Yogyakarta: STIK Aisyiyah Yogyakarta.

Walgito, B., 1994. Psikologi Sosial, Suatu Pengantar. Yogyakarta: Andi Offset.

Wowor, M., Laoh, J.M., Pangemanan, D.H.C., 2013. Hubungan Pengetahuan dan Sikap dengan Pemberian ASI Eksklusif pada Ibu Menyusui di Puskesmas Bahu Kota Manado. Ejurnal Keperawatan vol.1 no. 1 Agustus 2013 hal. 1-7. 